\title{
Distribution of trace elements in waters and sediments of the Seversky Donets transboundary watershed (Kharkiv region, Eastern Ukraine)
}

- $\quad$ Y. Vystavna ${ }^{a}, \underline{b}, \underline{c}$,

- $\underline{\text { F. Huneau }}^{\mathrm{a}, \underline{b}}$,

- J. Schäfer ${ }^{d}$,

- M. Motelica-Heino ${ }^{\mathrm{e}}$,

- G. Blanc,

- $\quad \underline{\text { A. Larrose }}$,

- $\underline{\text { Y. Vergeles }}{ }^{c}$,

- D. Diadin $^{\mathrm{c}}$,

- $\quad$ P. Le Coustumer ${ }^{\mathrm{a}}, \underline{b}$

- ${ }^{a}$ Université de Bordeaux, UFR Sciences de la Terre et de la Mer, B18, avenue des Facultés, F-33405 Talence, France

- $\quad$ b EA 4592, Géoressources \& Environnement, ENSEGID, 1 allée F. Daguin, F-33607 Pessac, France

- ${ }^{\mathrm{c}}$ National Academy of Municipal Economy at Kharkiv, Department of Environmental Engineering and Management, vul. Revolutsii 12, Kharkiv 61002, Ukraine

- ${ }^{\mathrm{d}}$ Université de Bordeaux, UMR CNRS 5805, Environnements et Paléoenvironnements Océaniques, F-33405 Talence, France

- $\quad$ e Université d'Orléans, UMR CNRS 6113, ISTO, Campus Géosciences, 1A rue de la Férollerie, F-41071 Orléans cedex 2, France

\begin{abstract}
This paper reports on the aquatic chemistry of trace elements in terms of spatial and temporal distribution, but also pollution sources in the transboundary watershed of the Seversky Donets River (Ukraine/Russia). Bed sediments and filtered water were collected from the Udy and Lopan Rivers at sites from the river source in the Belgorod region (Russia) to rural and urban areas in the Kharkiv region (Ukraine) in May and August 2009. Priority trace elements (As, $\mathrm{Cd}, \mathrm{Cr}, \mathrm{Cu}, \mathrm{Hg}, \mathrm{Ni}, \mathrm{Pb}$ and $\mathrm{Zn}$ ), an urban tracer ( $\mathrm{Ag}$ ) and additional metals (Co, Mo, $\mathrm{V}$ ) and Th were measured in stream water and sediments. The low levels and variability of Thnormalized concentrations indicated the absence of geochemical anomalies in the upstream part of the rivers and suggested that these data represent a regional baseline for trace elements in bed sediments. In contrast, water and sediments within the city of Kharkiv were contaminated by $\mathrm{Ag}, \mathrm{Pb}, \mathrm{Cd}, \mathrm{Cu}, \mathrm{Cr}$ and $\mathrm{Zn}$, which are mainly attributed to municipal wastewater inputs and urban run-off. Results of the environmental quality assessment showed that element concentrations in the sediments can be considered as potentially toxic to aquatic organisms in sites downstream of the wastewater discharges.
\end{abstract}




\section{Highlights}

- The observed spatial variations are mainly due to grain size variations. The regional background for trace elements in river sediments is defined. Water and sediments are contaminated by $\mathrm{Ag}, \mathrm{Pb}, \mathrm{Cd}, \mathrm{Cu}, \mathrm{Cr}$ and $\mathrm{Zn}$. Concentrations in the sediments are potentially toxic for the aquatic organisms.

\section{Introduction}

The presence of trace elements in rivers relates to the specific regional geochemistry and inputs from diverse anthropogenic sources. In the aquatic environment, trace elements can accumulate to toxic levels and cause severe effects to organisms and on human health (Gupta et al., 2009). Various factors, i.e. the climate and hydrology (Caruso and Bishop, 2009), water chemistry (Matache et al., 2009) and biological activity (van Hattum et al., 1996) control trace metal deposition and fixation in the sediments, which may act as both sinks and sources of secondary aquatic pollution (Pekey, 2006 and Coynel et al., 2007). The study of both water and sediment geochemistry is, therefore, necessary for the assessment of contamination status, the understanding and prevention of environmental risk and the development of regional and national water protection strategies (Neumann et al., 2005).

Eastern Ukraine, with a long history of large-scale industrial and agricultural activities through the soviet period up to present time (EPKhR, 2010), is one of the most urbanized regions in the country. The main river system of this part of Ukraine is the transboundary Seversky Donets watershed that also includes the Belgorod, Kursk and Rostov regions of the Russian Federation. The water resources are affected by the extensive multiple water uses (iron ore-mining processes, heavy and light manufacturing, power, industrial and drinking water supply infrastructures, agriculture, aquaculture) and urban inputs (NRDW, 2006). Regional and national environmental surveys in rivers of the Seversky Donets basin (Samarina, 2003 and Vasenko et al., 2006) have reported concentrations of dissolved Zn, Cr and $\mathrm{Pb}$ exceeding the valid Ukrainian water quality limits (GCPL, 1991 and SNPL, 1991). This pollution may induce environmental and health risks associated with drinking water supply and recreational activities in the region.

Despite the crucial role of the Seversky Donets basin in the social and economic development of neighboring regions of Ukraine and Russia, the recently established environmental monitoring network of the transboundary rivers is as yet insufficient (Vasenko et al., 2006, Vystavna et al., 2012a and Vystavna et al., 2012b) and concentrations, sources and fate of most trace elements in the watershed are poorly surveyed and understood. The existing monitoring and risk assessment suffers from very limited in situ measurements and poor sampling on the one hand and from the absence of information on regional sediment and water quality baselines on the other.

Two rivers of the Seversky Donets water basin, with a total catchment area in the Ukraine of $3460 \mathrm{~km}^{2}$, namely the Lopan and Udy Rivers, have been chosen as being representative of many other regional rivers in terms of general properties, watershed size and land use. These rivers have their sources in the Belgorod region (Russia) and flow downstream to the Kharkiv Region (Ukraine), where they receive substantial volumes (ca. 1000 thousands $\mathrm{m}^{3}$ per day) of domestic and industrial wastewaters from the urban area. 
This study is part of a research program on trace elements and emerging pollutants in the Kharkiv region (Vystavna et al., 2012a and Vystavna et al., 2012b) aiming at identifying and evaluating the geochemical baseline, actual levels and distributions of trace element concentrations in water and sediment, and also the major pollution sources to the Lopan and Udy Rivers. The paper discusses: (1) the spatial and temporal distribution of trace elements in water and sediments, (2) the regional geochemical baseline of trace elements in the sediments, and (3) the potential environmental risk of trace element contamination in sediments.

\section{Study area}

\subsection{General setting, hydroclimatology and hydrology}

The study area (Fig. 1) is situated in the Forest-Steppe natural zone of the southern slopes of the mid-Russian rolling plain with gray forest and thick grassland soil types, called chernozems (Samarina, 2007).

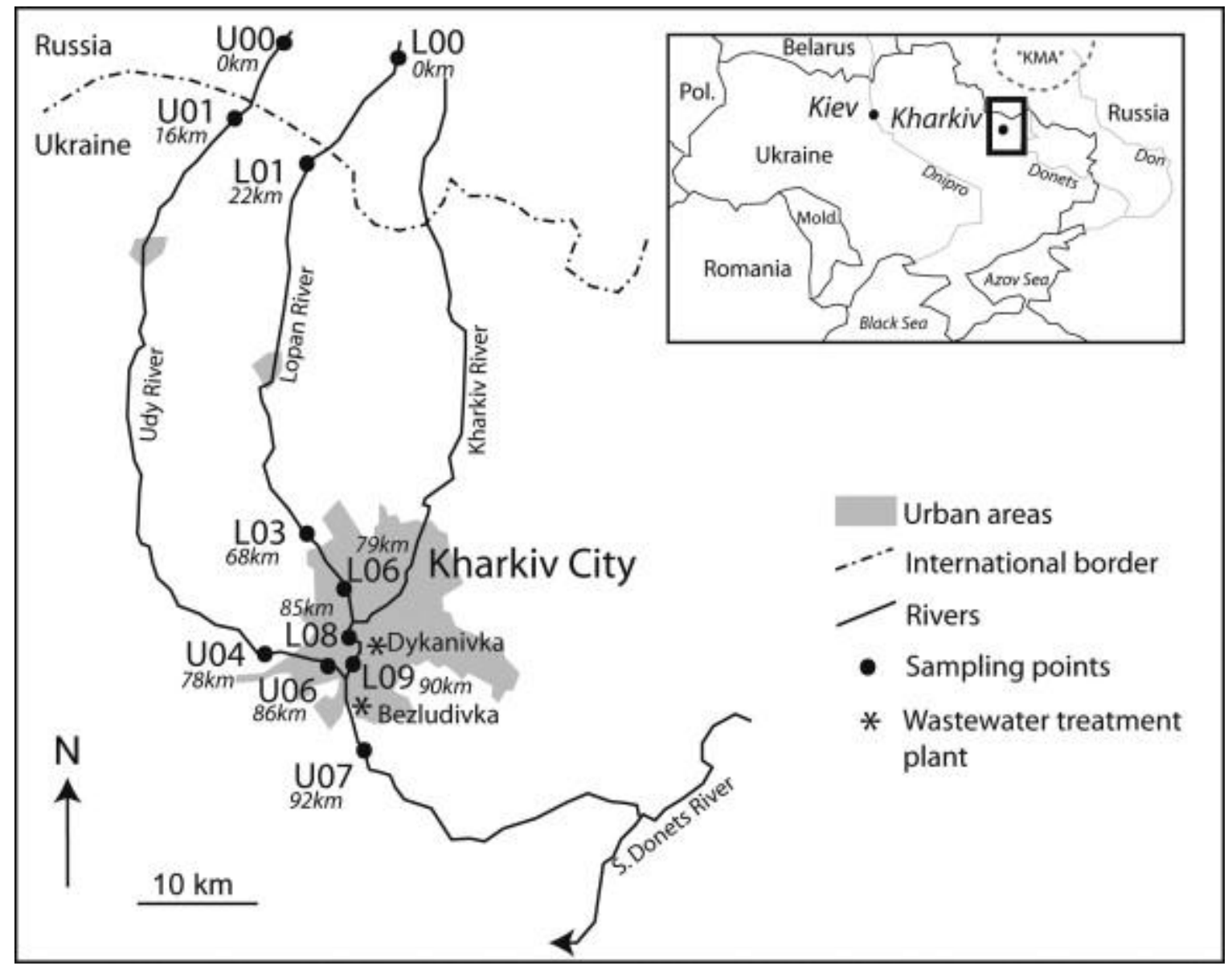

Fig.1. Location of the study area and the sampling sites ( $\mathrm{U}=$ Udy River, $\mathrm{L}=$ Lopan River). 
The duration of winter is from mid-November to mid-March and summer is from the midMay to early September. The coldest month is January (average temperature is $-7.1{ }^{\circ} \mathrm{C}$ ) and the warmest is July (average temperature is $+20.5^{\circ} \mathrm{C}$ ). The high temperature during the summer period and wastewater inputs induce pronounced seasonal $\mathrm{O}_{2}$-depletion and increase of nutrients in both studied rivers due to intense organic matter degradation (Vasenko et al., 2006). The mean annual air temperature is $7.6^{\circ} \mathrm{C}$ and rainfall varies between 470 and $540 \mathrm{~mm} / \mathrm{a}$ with $145-160 \mathrm{~mm}$ precipitation in winter and 140-190 $\mathrm{mm}$ in summer (Jakovljev et al., 2002). The Lopan and Udy Rivers are quite shallow (from 0.4 to $2.3 \mathrm{~m}$ in depth) and their flows are regulated by several dams along their watercourses. The mean high water discharge of the Lopan River is $1.4 \mathrm{~m}^{3} \mathrm{~s}^{-1}$ (winter and spring) and the mean low water discharge is $0.9 \mathrm{~m}^{3} \mathrm{~s}^{-1}$ (summer). The high water discharge of the Udy River is $6.8 \mathrm{~m}^{3} \mathrm{~s}^{-1}$ (winter and spring) and mean low water discharge is $2.5 \mathrm{~m}^{3} \mathrm{~s}^{-1}$ (summer). Water discharge is measured at sampling sites located about $1 \mathrm{~km}$ upstream from Kharkiv city (Vasenko et al., 2006). The rivers are fed mostly by rainfall and partly by groundwater from Tertiary aquifers (Jakovljev et al., 2002). The above-mentioned hydrological parameters (small size, low flow rate, man-made regulation) of these rivers suggest that both water bodies have very limited natural purification potential (Vasenko et al., 2006).

\subsection{Geology}

The north-eastern part of Ukraine belongs to the Dnieper-Donets depression and to the Voronezh anticline of the Eastern European Platform. The Precambrian crystalline basement in the axial part of this structure outcrops to the NE of the platform (Jakovljev et al., 2002) and is covered by Paleozoic, Mesozoic and Cenozoic sedimentary deposits such as sandstones, clays, argillites, siltstones and limestones. The uppermost formations in the study area consist of Cretaceous, Paleogene, Neogene and Quaternary deposits. The water-bearing sands in the Cretaceous (Cenomanian) deposits are protected from pollution by a layer of marls and chalk and are used for municipal water supply in the Sumy, Poltava and Kharkiv regions (Jakovljev et al., 2002). Oligocene, Eocene and Pliocene-Quaternary aquifers are also widely used by the local population for additional drinking water supply, in spite of the high $\mathrm{NO}_{3}^{-}$content (Jakovljev et al., 2002).

The northern part of the study area is about $100 \mathrm{~km}$ from the Yakovlevka deposit (in the Belgorod region of Russia) which is a part of the Precambrian banded iron formation of the iron-ore basin called the Kursk Magnetic Anomaly (KMA) (Fig. 1). The deposit contains residual, partially weathered ores with high concentrations of $\mathrm{Cu}, \mathrm{Zn}, \mathrm{As}, \mathrm{Cd}, \mathrm{Ag}$ and $\mathrm{U}$ compared to the average continental crust (Belykh et al., 2007). Samarina, 2003, Samarina, 2007 and Samarina, 2008 has reported that the exploitation of the KMA deposits in the Belgorod region (mining, iron ore-processing, metallurgy and corresponding infrastructure) has induced negative impacts on the environment and water quality of regional watercourses, increasing groundwater mineralization and concentrations of $\mathrm{Cu}, \mathrm{Zn}, \mathrm{Pb}$ and $\mathrm{Cr}$.

\subsection{Water use}

The upper parts of the Lopan and Udy River basins feature mostly rural land-uses while the middle and lower parts incorporate the urban agglomeration of the city of Kharkiv with a population density of 4764 persons $/ \mathrm{km}^{2}$ and a total population of ca. 2 million (as of 2009; EPKhR, 2010). 
In the Kharkiv region, the studied rivers are mainly used for water supply and wastewater discharge. The 'Dykanivka' (700,000 $\left.\mathrm{m}^{3} \mathrm{~d}^{-1}\right)$ and the 'Bezludivka' $\left(300,000 \mathrm{~m}^{3} \mathrm{~d}^{-1}\right)$ are two large-size wastewater treatment plants (WWTPs) which receive and treat mixed industrial effluents mainly from machinery, coke-processing, food-processing, light industry $(25 \%$ of all influents) and domestic (75\% of all influents) wastewaters from the Kharkiv agglomeration. The wastewater treatment includes mechanical and biological (aerobic) processes with a final disinfection step by chlorination. The volume of treated wastewater released by the 'Dykanivka' WWTP ('D'WWTP) into the Lopan River is more than twice as high as the natural river discharge, which causes aquatic pollution by suspended solids, labile organic matter, $\mathrm{Cl}^{-}, \mathrm{NO}_{2}^{-}, \mathrm{NO}_{3}^{-}, \mathrm{NH}_{4}^{+}$, oil products and phenols and intensify eutrophication processes in the Lopan during summer (Vasenko et al., 2006). The 'Bezludivka" WWTP ('B'WWTP) discharges treated wastewaters into the Udy River and is responsible for the accumulation of $\mathrm{Cr}, \mathrm{Zn}, \mathrm{Cu}$ and $\mathrm{Pb}$ in the sediments downstream from the wastewater treatment plant. The river pollution has been attributed to the low efficiency of existing treatment processes, absence of manufacturing wastewater pre-treatment technologies and mixing of industrial and domestic wastewaters (Vasenko et al., 2006).

\subsection{Sampling localities}

The sampling sites were selected to monitor and identify potential trace element sources (transboundary upstream area, agricultural versus urban regions, wastewater discharges) and chosen on the basis of the results of the previous monitoring (Vystavna et al., 2009 and Vystavna et al., 2012b). Sampling was conducted at six sites on the Lopan River (Fig. 1): (1) site L00 is close to the river source in the agricultural area of the Belgorod region, Russia; (2) site L01 is in the agricultural area of the Kharkiv region, Ukraine, (3) site L03 represents the river section upstream from the Kharkiv urban agglomeration; (4) site L06 is in Kharkiv city centre; (5) L08 is within the urban area and upstream of the wastewater outlet of 'D'WWTP; (6) L09 is downstream from the 'D'WWTP and upstream from the confluence of the Lopan and Udy Rivers.

Similarly, five sampling sites on the Udy River (Fig. 1) were selected: (1) U00 is near to the river source in the agricultural area of the Belgorod region, Russia, (2) U01 is in the agricultural area of the Kharkiv region, Ukraine; (3) U04 is upstream from the Kharkiv urban agglomeration, (4) U06 is in the urban area, upstream of the Lopan-Udy confluence and upstream from the wastewater outlet of 'B'WWTP and (5) U07 is downstream from the discharge of the 'B'WWTP and the Lopan-Udy Rivers confluence (Fig. 1). The transboundary sites L00 and U00 were sampled only once (May 2009) due to administrative problems related to the crossing of the Russian border, whereas the other sites were sampled twice in May and August 2009 in order to represent contrasting hydrological processes in rivers. During May, the discharge is relatively high, mainly due to snow melt in the MarchApril period, whereas during August, the river discharge is decreased and mainly derived from groundwater inflow. During August, water temperature and eutrophication-related processes are at their maxima (Vasenko et al., 2006).

\section{Materials and methods}

Priority substances (i.e. As, $\mathrm{Cd}, \mathrm{Cu}, \mathrm{Cr}, \mathrm{Hg}, \mathrm{Ni}, \mathrm{Pb}$ and $\mathrm{Zn}$; European Community Directive on Priority Substances 2008/105/EC; EU Water Framework Directive 2000/60/EC; Tueros et al., 2009), Ag (urban tracer; Feng et al., 1998) and other elements of environmental concern (Co, Mo, V; Schäfer et al., 2009) were determined in water and sediments. 


\subsection{In situ measurements and dissolved phase sampling}

Water temperature, $\mathrm{pH}$ and electrical conductivity were measured in situ at $1 \mathrm{~m}$ from the river bank and at $0.2 \mathrm{~m}$ depth using a WTW Multiline P4 probe. Total organic C (TOC) was determined from spot unfiltered samples and measured using a TOC-5000, Shimadzu ( automated analyser following ISO 10694.

River water was sampled at $1 \mathrm{~m}$ from the bank and at $0.2 \mathrm{~m}$ depth using an acid-cleaned $50 \mathrm{~mL}$ syringe and immediately filtered through $0.2 \mu \mathrm{m}$ cellulose-acetate membranes (Nucleopore filters) acidified $\left(\mathrm{HNO}_{3}\right.$, ultrapure; $1 / 1000 \mathrm{v} / \mathrm{v}$; as described in Masson et al., 2009 and Lanceleur et al., 2011 and stored in acid cleaned $16 \mathrm{~mL}$ polypropylene tubes at $4{ }^{\circ} \mathrm{C}$ and in the dark pending analysis.

\subsection{Sediment sampling and digestion}

Sediments were collected close to the river bank and stored in sterile capped containers. In the laboratory, the samples were sieved to pass $<63 \mu \mathrm{m}$, dried to constant weight at $50{ }^{\circ} \mathrm{C}$, powdered, homogenized and stored in closed polyacrylate containers $(50 \mathrm{~mL})$. Representative subsamples (30 mg of dry homogenized sediment) were digested at $110{ }^{\circ} \mathrm{C}$ for $2 \mathrm{~h}$ in acidcleaned closed reactors with $1.5 \mathrm{~mL} \mathrm{HCl}\left(12 \mathrm{M}\right.$, suprapure), $0.75 \mathrm{~mL} \mathrm{HNO}_{3}(14 \mathrm{M}$, suprapure) and $2 \mathrm{~mL} \mathrm{HF}$ (26 M, suprapure), using a temperature-controlled digestion system (Digi PREP MS ${ }^{\circledR}$, SCP SCIENCE). After cooling, the digested samples were made up to $10 \mathrm{~mL}$ using $250 \mu \mathrm{L} \mathrm{HNO}_{3}(14 \mathrm{M}$, suprapure) and double deionized (Milli-Q®) water, then stored in the dark at $4{ }^{\circ} \mathrm{C}$ awaiting analysis by ICP-MS. Parallel blank digestions (without sediment) and analyses of international certified reference sediments (IAEA-405 and CRM 320) allowed estimating accuracy and precision of the blank-corrected sediment analyses (Table 1). 
Table 1. Accuracy and detection limits for water and sediment sampling and analysis.

$\begin{array}{lllllllllllllll}\text { Trace element } & \mathrm{Ag} & \mathrm{As} & \mathrm{Cd} & \mathrm{Co} & \mathrm{Cr} & \mathrm{Cu} & \mathrm{Hg} & \mathrm{Mo} & \mathrm{Ni} & \mathrm{Pb} & \mathrm{Th} & \mathrm{V} & \mathrm{Zn}\end{array}$ Water sampling (total dissolved metal(loid)s)

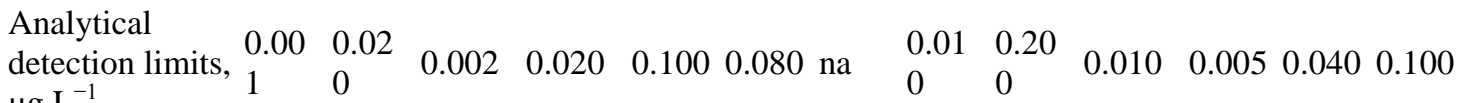
$\mu \mathrm{g} \mathrm{L}{ }^{-1}$

Certified reference material $-S L R S 4(n=10)$

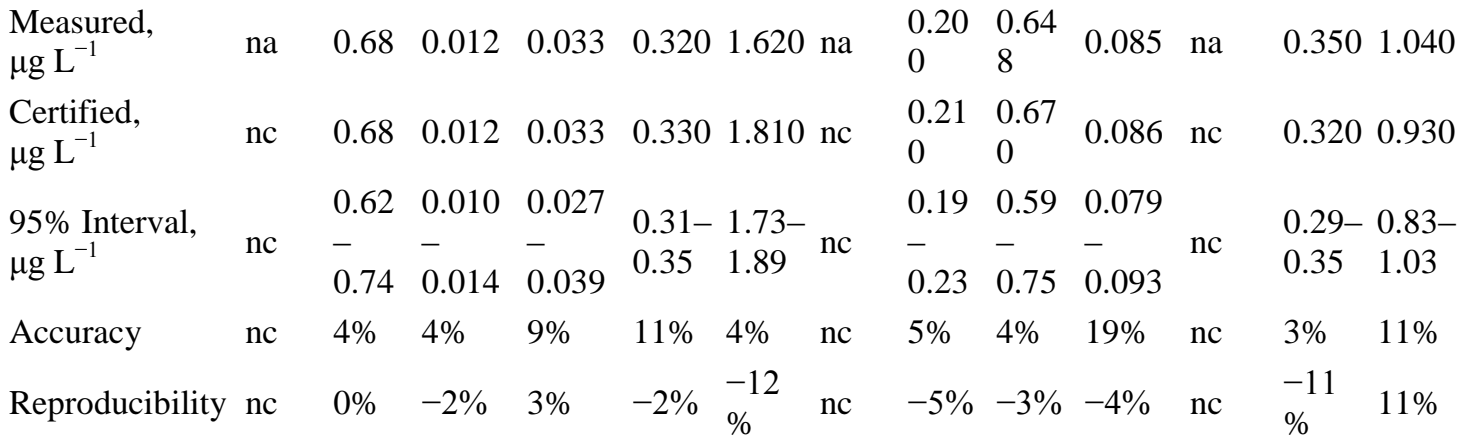

Sediments sampling

Certified reference material - CRM $320(n=16)$

\begin{tabular}{|c|c|c|c|c|c|c|c|c|c|c|c|c|c|}
\hline $\begin{array}{l}\text { Measured, } \\
{\mu \mathrm{g} \mathrm{kg}^{-1}}\end{array}$ & na & 75.7 & 0.59 & 18.6 & 122 & 40.1 & na & 0.61 & 81.7 & 38.8 & 10.9 & 96.3 & 128 \\
\hline $\begin{array}{l}\text { Certified, } \\
\mu \mathrm{g} \mathrm{kg}^{-1}\end{array}$ & $\mathrm{nc}$ & 76.7 & 0.53 & $\mathrm{nc}$ & 138 & 44.1 & 1.03 & $\mathrm{nc}$ & 75.2 & 42.3 & $\mathrm{nc}$ & $\mathrm{nc}$ & 142 \\
\hline $\begin{array}{l}95 \% \text { Interval, } \\
\mu \mathrm{g} \mathrm{kg}^{-1}\end{array}$ & $\mathrm{nc}$ & $\begin{array}{l}73.3 \\
- \\
80.1\end{array}$ & $\begin{array}{l}0.51- \\
0.56\end{array}$ & $\mathrm{nc}$ & $\begin{array}{l}138- \\
145\end{array}$ & $\begin{array}{l}43.1- \\
45.1\end{array}$ & $\begin{array}{l}0.90 \\
- \\
1.16\end{array}$ & $\mathrm{nc}$ & $\begin{array}{l}73.8 \\
- \\
76.6\end{array}$ & $\begin{array}{l}40.7- \\
43.9\end{array}$ & $\mathrm{nc}$ & $\mathrm{nc}$ & $\begin{array}{l}139- \\
145\end{array}$ \\
\hline Accuracy & $\mathrm{nc}$ & $-1 \%$ & $10 \%$ & $\mathrm{nc}$ & $\begin{array}{l}-12 \\
\%\end{array}$ & $-9 \%$ & na & $\mathrm{nc}$ & $9 \%$ & $-8 \%$ & $\mathrm{nc}$ & $\mathrm{nc}$ & $\begin{array}{l}-10 \\
\%\end{array}$ \\
\hline $\begin{array}{l}\text { Reproducibilit } \\
\mathrm{y}\end{array}$ & $\mathrm{nc}$ & $7 \%$ & $6 \%$ & $8 \%$ & $4 \%$ & $8 \%$ & na & $14 \%$ & $8 \%$ & $7 \%$ & $14 \%$ & $5 \%$ & $21 \%$ \\
\hline \multicolumn{14}{|c|}{ Certified reference material - IAEA $405(n=10)$} \\
\hline $\begin{array}{l}\text { Measured, } \\
\mu \mathrm{g} \mathrm{kg}^{-1}\end{array}$ & 1.06 & 24.6 & 0.80 & 13.6 & 81.4 & 48.0 & $\begin{array}{l}0.78 \\
7\end{array}$ & 0.66 & 32.8 & 78.9 & 12.4 & 94.5 & 277 \\
\hline $\begin{array}{l}\text { Certified, } \mu \mathrm{g} \\
\mathrm{kg}^{-1}\end{array}$ & $\mathrm{nc}$ & 23.6 & 0.73 & 13.7 & 84 & 47.7 & 0.81 & $\mathrm{nc}$ & 32.5 & 74.8 & 14.3 & 95 & 279 \\
\hline $\begin{array}{l}95 \% \text { Interval, } \\
\mu \mathrm{g} \mathrm{kg}^{-1}\end{array}$ & $\mathrm{nc}$ & $\begin{array}{l}22.9 \\
- \\
24.3\end{array}$ & $\begin{array}{l}0.68- \\
0.78\end{array}$ & $\begin{array}{l}13.0- \\
14.4\end{array}$ & $\begin{array}{l}80.0- \\
88.0\end{array}$ & $\begin{array}{l}46.5- \\
48.9\end{array}$ & $\begin{array}{l}0.77 \\
- \\
0.85\end{array}$ & $\mathrm{nc}$ & $\begin{array}{l}31.1 \\
- \\
33.9\end{array}$ & $\begin{array}{l}72.6- \\
77.0\end{array}$ & $\begin{array}{l}12.2- \\
16.4\end{array}$ & $\begin{array}{l}90- \\
100\end{array}$ & $\begin{array}{l}272- \\
286\end{array}$ \\
\hline Accuracy & $\mathrm{nc}$ & $4 \%$ & $10 \%$ & $-1 \%$ & $-3 \%$ & $1 \%$ & $-3 \%$ & $\mathrm{nc}$ & $1 \%$ & $5 \%$ & $\begin{array}{l}-13 \\
\%\end{array}$ & $0 \%$ & $-1 \%$ \\
\hline $\begin{array}{l}\text { Reproducibilit } \\
\mathrm{y}\end{array}$ & $6 \%$ & $9 \%$ & $12 \%$ & $4 \%$ & $3 \%$ & $7 \%$ & $4 \%$ & $6 \%$ & $8 \%$ & & & & \\
\hline
\end{tabular}




\subsection{Analyses}

Total dissolved element concentrations in filtered $(<0.2 \mu \mathrm{m})$ water samples and sediment digests were measured by ICP-MS (X7, Thermo). The results were consistently within the range of certified values for SLRS-4 (water), CRM 320 and IAEA405 (sediments) and the analytical error (relative standard deviation) was generally better than 5\% (Table 1). The procedure and results were in accordance with previous studies performed in the EPOC-TGM laboratory (e.g. Schäfer and Blanc, 2002 and Audry et al., 2004). Mercury concentrations were determined on dry, homogenized sediments by cold vapor atomic absorption spectrometry after calcination in an $\mathrm{O}_{2}$-stream and amalgamation using an automated $\mathrm{Hg}$ analyser (MILESTONE, DMA-80; Schäfer et al., 2006). The results obtained for the international certified reference sediment IAEA 405 were consistently within the ranges of the certified values and precision was better than 5\% (RSD) (Table 1).

\subsection{Enrichment Factor estimation}

In order to determine the degree of contribution of the urban area to the sediment composition, the Enrichment Factor (EF) was calculated using the following equation (e.g. Pekey, 2006):

$$
(\mathrm{EF})=\left(C_{x} / C_{\mathrm{Th}}\right)_{\mathrm{sample}} /\left(C_{x} / C_{\mathrm{Th}}\right)_{\mathrm{crust}}
$$

where $\left(C_{x} / C_{\mathrm{Th}}\right)_{\text {sample }}$ is the ratio of concentration of the element being measured $\left(C_{x}\right)$ to that of $\mathrm{Th}\left(C_{\mathrm{Th}}\right)$ in the sediment sample and $\left(C_{x} / \mathrm{C}_{\mathrm{Th}}\right)_{\text {crust }}$ is the respective baseline ratio. Thorium has been used as a normaliser to compensate the constituent variability in sediments resulting from grain size variations (Coynel et al., 2007). According to Pekey (2006), elements can be divided into three major groups with respect to their corresponding Enrichment Factors: elements without enrichment $(\mathrm{EF}<10)$, elements with medium-level enrichment $(10<\mathrm{EF}<100)$ and highly enriched elements $(\mathrm{EF}>100)$

\subsection{Environmental impact assessment}

To evaluate the sediment contamination and potential eco-toxicological effects associated with the observed contaminant concentration, the commonly applied Sediment Quality Guidelines (SQGs; MacDonald et al., 2000, Ingersoll et al., 2001 and Zheng et al., 2008) were used and also the guidelines for the environmental quality assessment widely used in Ukraine (Saet et al., 1990).

SQGs developed for freshwater ecosystems are useful tools to assess the potential ecotoxicology of contaminants in sediments taking into account the consensus-based Threshold Effect Concentration (TEC) and Probable Effect Concentration (PEC) (MacDonald et al., 2000, Ingersoll et al., 2001 and Binelli et al., 2008).

The mean probable effect concentration quotient (m-PEC-Q) which aims at estimating the probability of acute sediment toxicity due to the possible biological effects of toxic mixtures has been calculated according to MacDonald et al. (2000):

$$
\mathrm{m}-\mathrm{PEC}-\mathrm{Q}=\frac{\sum_{i=1}^{n}\left(C_{i} / P E C_{i}\right)}{n}
$$


where $C_{i}$ is the sediment concentration of the $i$ compound, $P E C_{i}$ is the $P E C$ for the $i$ compound and $n$ is the number of considered compounds.

Samples with mean PEC quotients $<0.5$ were predicted to be non-toxic, whereas sediments with mean PEC quotients > 0.5 may be considered as potentially toxic (MacDonald et al., 2000, Ingersoll et al., 2001 and Zheng et al., 2008). However, recent work has shown that the reliability of this commonly applied approach depends on several factors which could affect trace element availability from sediment to biota such as sediment grain size, organic matter content or trace element speciation (Casado-Martinez et al., 2006 and Choueri et al., 2009).

The environmental risk assessment according to the Ukrainian approach requires the comparison of trace element concentrations with their respective regional baseline values in sediments or/and in the continental crust (Saet et al., 1990 and Svirenko et al., 2003). This approach is used both for soil and sediment environmental risk assessments. According to the proposed approach, the coefficient of concentration $K_{c i j}$ was calculated for each $i$ th element in each $j$ th sample:

$Z_{c}=\left.\sum_{i=1}^{n}\left(K_{c i j}\right)\right|_{K c i j \geq 1.2}-(n-1)$

A cumulative sediment (soil) contamination index $Z_{c j}$ was calculated for each $j$ th sample as follows:

$K_{c i j}=C_{i j} / C_{i b}$

where $C_{i j}$ is a concentration of the $i$ th element in sediment (soil) in the $j$ th sediment (soil) sample, $C_{i b}$ is a baseline concentration of the $i$ th element in a large geochemical region; only those elements for which the ratio $C_{i} / C_{i b}$ is $\geqslant 1.2$ (considering the standard error of the estimated ratio $\leqslant 20 \%$ ) were included in the calculation, and $n$ is the number of such elements. The degree of contamination and related environmental risk is considered as moderate if $Z_{c}$ is $\leqslant 16$, as significant if $16<Z_{c} \leqslant 32$ and as very high for $32<Z_{c} \leqslant 128$, and as dangerous for $Z_{c}>128$ (Saet et al., 1990).

\section{Results}

\subsection{Distribution of trace elements in the water}

According to major ion concentrations (Vasenko et al., 2006), water of both rivers is classified as of $\mathrm{HCO}_{3}-\mathrm{Ca}$ type $\left(\mathrm{HCO}_{3}^{-}>\mathrm{SO}_{4}^{2-}>\mathrm{Cl}^{-}\right.$and $\left.\mathrm{Ca}^{2+}>\mathrm{Na}+\mathrm{K}>\mathrm{Mg}^{2+}\right)$, which is in agreement with the petrographic nature of the river beds and may be explained by interactions of the water with Cretaceous carbonate rocks. The $\mathrm{pH}$ of both rivers ranged from 7.4 to 8.2. Electrical conductivity showed variations in both rivers with the maximum value at the sites downstream of the inflow of the wastewater discharges by the ' $\mathrm{D}$ ' WWTP and 'B'WWTP (site U07). Water temperature varied from 13 to $16^{\circ} \mathrm{C}$ in May to $16-23{ }^{\circ} \mathrm{C}$ in August in both rivers (Table 2). 
Table 2. Temperature, $\mathrm{pH}$, conductivity and total organic $\mathrm{C}$ at the sampling sites along the Lopan and Udy Rivers.

May 2009

August 2009

Site

\begin{tabular}{lllllll}
\multicolumn{2}{c}{$\boldsymbol{T}\left({ }^{\circ} \mathbf{C}\right)$} & $\mathbf{p H} \boldsymbol{E}\left(\boldsymbol{\mu S} \mathbf{~ c m}^{-\mathbf{1}}\right)$ & $\mathbf{T O C}\left(\mathbf{m g ~ L}^{-\mathbf{1})} \boldsymbol{T}\left({ }^{\circ} \mathbf{C}\right) \mathbf{p H} \boldsymbol{E}\left(\boldsymbol{\mu S ~} \mathbf{c m}^{-\mathbf{1}}\right) \mathbf{T O C}\left(\mathbf{m g ~ L}^{-\mathbf{1}}\right)\right.$ \\
U00 13 & 8.2468 & nd & nd & nd nd & nd \\
U01 14 & 7.8865 & 71 & 16 & 7.7925 & 87 \\
U04 14 & 8.2930 & 68 & 21 & 8.1971 & 84 \\
U06 14 & 7.81080 & 57 & 20 & 7.41220 & 65 \\
U07 16 & 7.31240 & 50 & 22 & 7.21380 & 53 \\
L00 12 & 7.71035 & nd & nd & nd nd & nd \\
L01 13 & 7.81080 & 171 & 16 & 7.91070 & 173 \\
L03 14 & 7.81140 & 85 & 17 & 7.7799 & 99 \\
L06 14 & 7.91080 & 103 & 18 & 7.8787 & 133 \\
L08 15 & 7.81100 & 98 & 20 & 7.6901 & 105 \\
L09 16 & 7.41240 & 47 & 23 & 7.21340 & 51
\end{tabular}

nd - the parameter has not been determined.

The concentrations of dissolved $\mathrm{Ni}$ in August and $\mathrm{Ag}$ in both seasons were below detection limits (i.e. $<0.001 \mu \mathrm{L}^{-1}(\mathrm{Ag})$ and $<0.200 \mu \mathrm{L}^{-1}(\mathrm{Ni})$ ). Dissolved As, Co, V and Mo in the water showed no significant increase in concentration from rural to urban parts of the rivers. In contrast, concentrations of dissolved $\mathrm{Cd}, \mathrm{Cr}, \mathrm{Cu}, \mathrm{Ni}, \mathrm{Pb}$ and $\mathrm{Zn}$ in water were higher in the urban area compared to the rural reaches (Table 3), with peaks at the sites (U07 and L09) located downstream from the discharges of 'B'WWTP and 'D'WWTP (Table 3). The results show that the TOC contamination tended to decrease in sites located downstream of wastewater discharges (Table 2), thereby, complexation processes should be less intensive in this part compared to the upstream. 
Table 3. Dissolved trace element concentrations in surface water $\left(\mu \mathrm{g} \mathrm{L}^{-1}\right)$ and particulate trace element concentration in the sediments $\left(\mathrm{mg} \mathrm{kg}^{-1}\right)$ from the Lopan and Udy Rivers.

\section{Site}

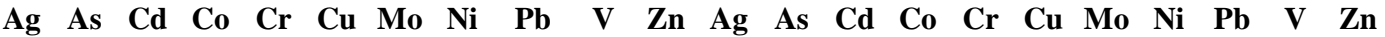
Total dissolved metal(loid)s concentration in water

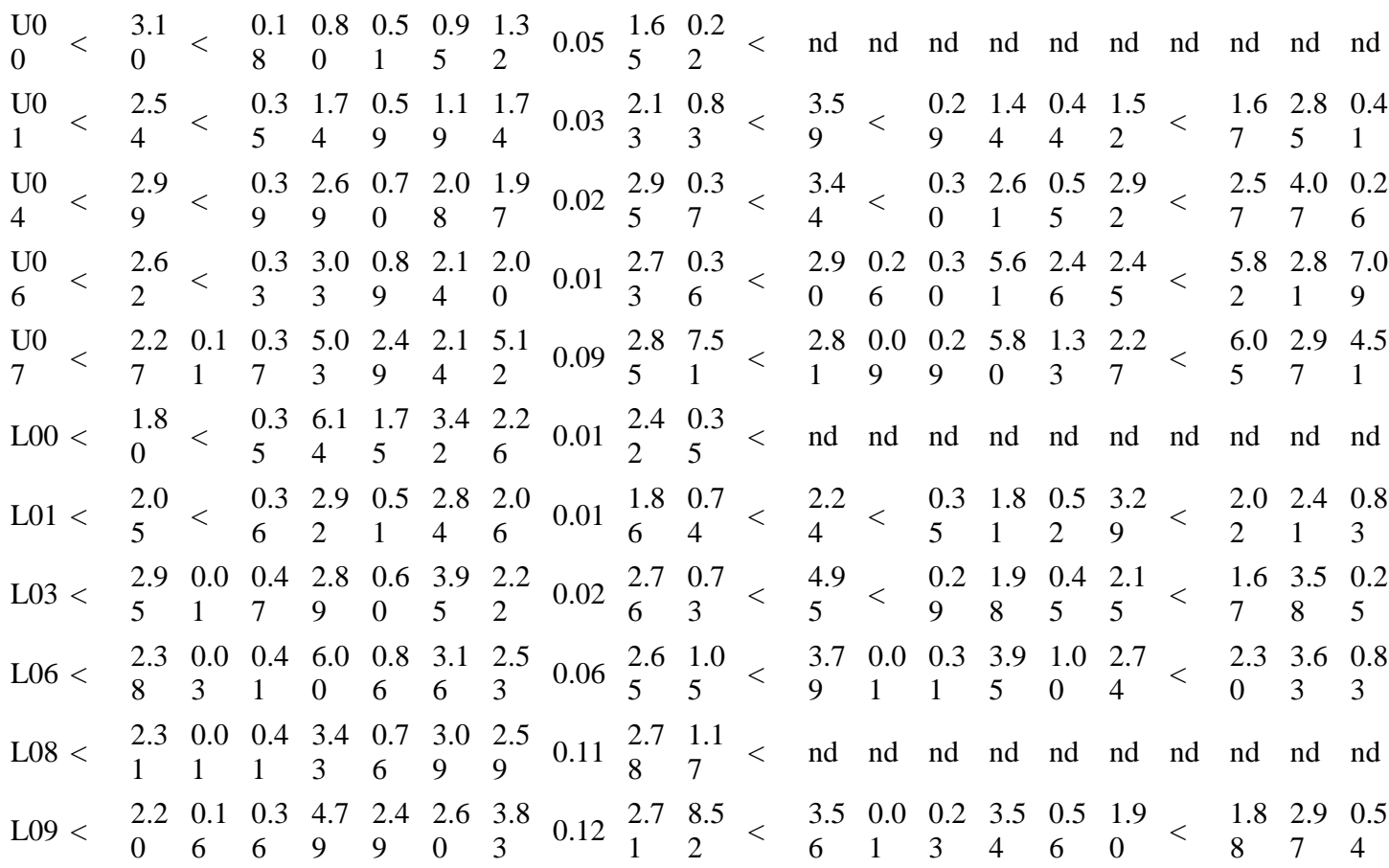

\section{Sediment concentration}

$\begin{array}{llllllllllllll}\text { U0 } & 0.3 & 13 & 0.3 & 17 & 86 & 26 & 1.0 & 53 & 23.5 & 122 & 81 \\ 0 & 2 & 9 & 4 & 0 & 7 & 8 & 1 & 0 & 2 & 2 & 2\end{array}$ nd nd nd nd nd nd nd nd nd nd nd

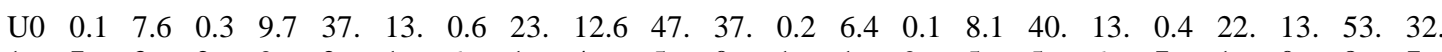
$\begin{array}{lllllllllllllllllllllll}1 & 7 & 3 & 2 & 9 & 2 & 1 & 6 & 1 & 4 & 5 & 0 & 1 & 1 & 9 & 5 & 5 & 6 & 7 & 1 & 0 & 8 & 7\end{array}$ $\begin{array}{lllllllllllllllllllllll}\mathrm{U} 0 & 0.0 & 3.1 & 0.0 & 2.6 & 11 & 3.1 & 0.5 & 3.9 & 5.8 & 18 . & 8.3 & 0.0 & 1.6 & 0.1 & 3.0 & 12 . & 0.5 & 13 . & 4.4 & 18 . & 8.3 \\ 4 & 7 & 9 & 6 & 0 & 4 & 1.1 & 1 & 0 & 5.8 & 2 & 8.3 & 7 & 8 & 8 & 3 & 4 & 4.5 & 4 & 3 & 4.4 & 2 & 0\end{array}$

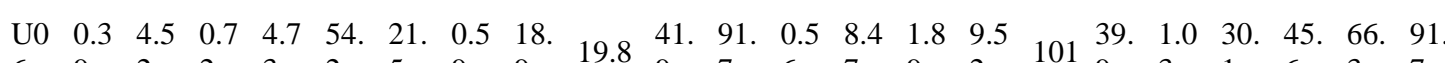
$\begin{array}{lllllllllllllllllllllll}6 & 9 & 2 & 2 & 3 & 2 & 5 & 9 & 9 & 19.8 & 9 & 7 & 6 & 7 & 9 & 2 & 101 & 9 & 3 & 1 & 6 & 3 & 7\end{array}$ $\begin{array}{lllllllllllllllllllllll}\text { U0 } & 0.7 & 0.9 & 3.4 & 1.1 & 113 & 101 & 0.2 & 13 & 13.1 & 9.1 & 76 & 0.6 & 0.9 & 3.5 & 1.0 & 100 & 38 . & 0.2 & 12 . & 9.6 & 8.6 & 76\end{array}$

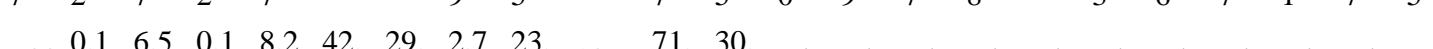

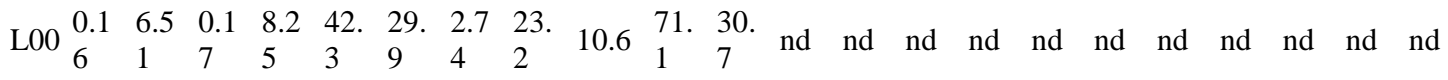
$\begin{array}{lllllllllllllllllllllll}\text { L01 } & 0.3 & 9.9 & 0.3 & 12 & 76 & 24 & 1.2 & 38 & 24.5 & 101 & 71 . & 0.2 & 7.7 & 0.3 & 8.4 & 53 . & 15 . & 3.5 & 26 . & 14 . & 73 . & 46 .\end{array}$ $\begin{array}{lllllllllllllllllllllll}\mathrm{L} 03 & 0.2 & 4.9 & 0.3 & 6.1 & 44 & 15 & 0.8 & 21 & 19.9 & 50 . & 59 & 0.2 & 7.6 & 0.3 & 8.3 & 58 . & 24 & 1.0 & 30 . & 28 & 73 . & 78 .\end{array}$

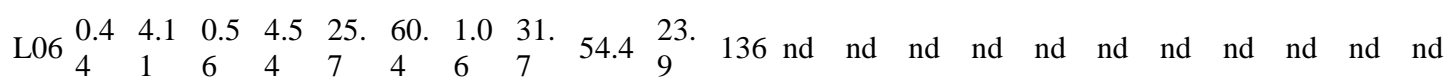

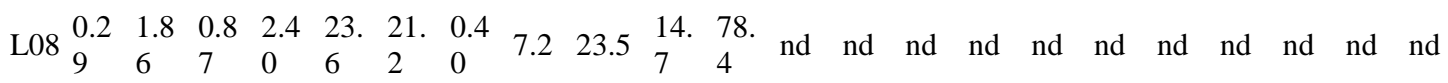

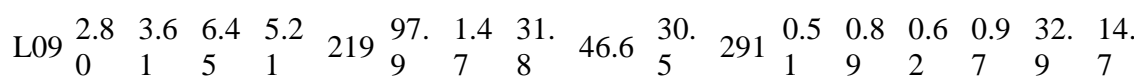




\subsection{Normalization by ${ }^{232} \mathrm{Th}$ and distribution of trace elements in sediments}

The concentrations of trace elements (Ag, As, $\mathrm{Cd}, \mathrm{Co}, \mathrm{Cr}, \mathrm{Cu}, \mathrm{Hg}, \mathrm{Mo}, \mathrm{Ni}, \mathrm{Pb}, \mathrm{Th}, \mathrm{V}$ and $\mathrm{Zn}$ ) in sediments showed spatial variability along the studied watercourses (Table 3), varying by factors up to 33 (Fig. 2). Taking into account, that suspended sediments in the rivers consist of detrital particles including silts, clays and fine sands (Vasenko et al., 2006), grain size segregation due to particle settling during sediment transport may affect element concentrations in the sediments. Therefore, Th-normalized values were used to calculate Enrichment Factors (EFs). Data on the Earth's crust composition proposed by Vinogradov (1962) was applied as the regional reference baseline (Yaroshevsky, 2006) for the study area. Arsenic, $\mathrm{Co}, \mathrm{Hg}, \mathrm{Mo}, \mathrm{Ni}$ and $\mathrm{V}$ had $\mathrm{EF}<10$, so they were considered as elements without significant enrichment for the sampling sites for both the Lopan and Udy Rivers (Table 4). Other elements like $\mathrm{Ag}, \mathrm{Cr}, \mathrm{Cu}, \mathrm{Pb}$ and $\mathrm{Zn}$ showed no enrichment at the sites upstream from the urban area (L00-L03 and U00-U04), but within the urban area the Enrichment Factors of these elements ranged from 10 to 100, reflecting medium enrichment. The highest EF for Ag, $\mathrm{Cr}, \mathrm{Cu}$ and $\mathrm{Zn}$ occurred at the sites downstream of the wastewater discharges from ' $\mathrm{D}$ 'WWTP and 'B' WWTP. Lead showed its highest value $(E F=10)$ at site $L 06$ in the city centre, where it can enter in run-off and atmospheric deposition from the traffic routes. Silver was the element with the highest Enrichment Factor (EF from 53.0 to 89.0) in both rivers downstream of the wastewater discharges (L09 and U07). 
Direct concentrations
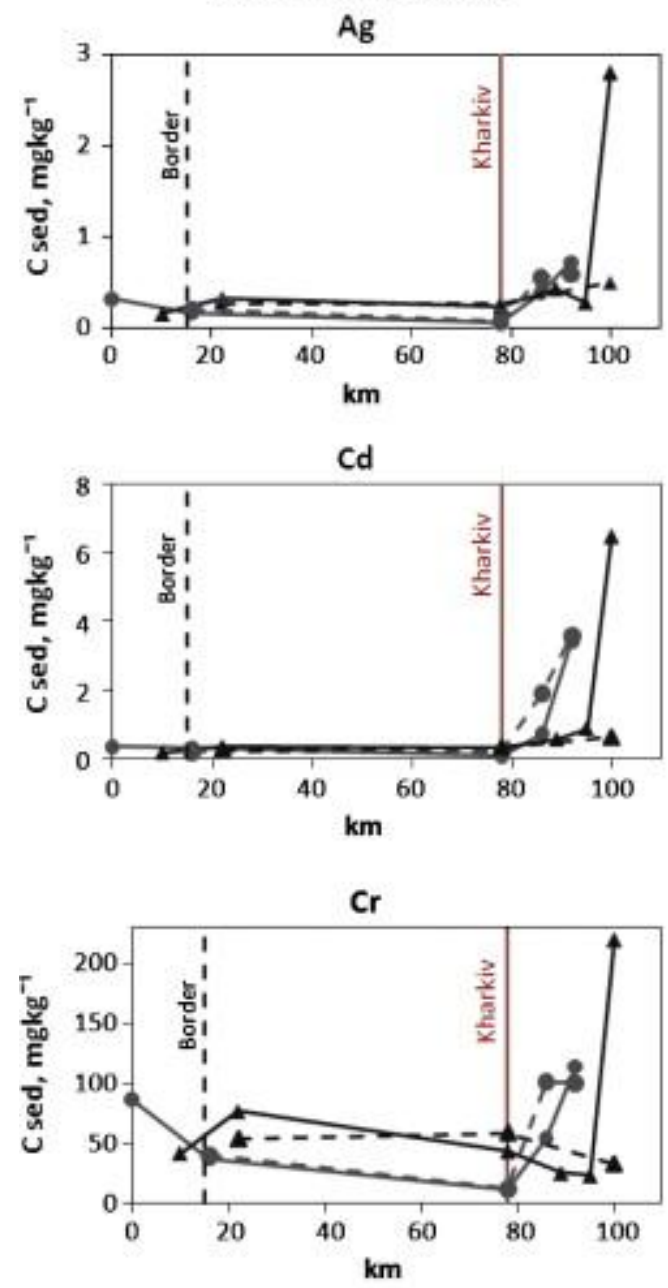

$\mathrm{Cu}$

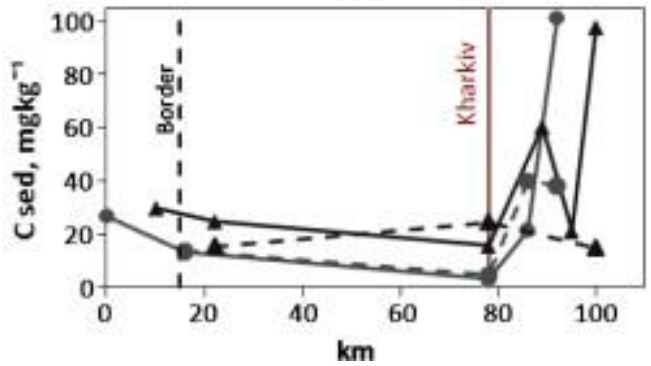

Th normalized concentrations

$\mathrm{Ag}$
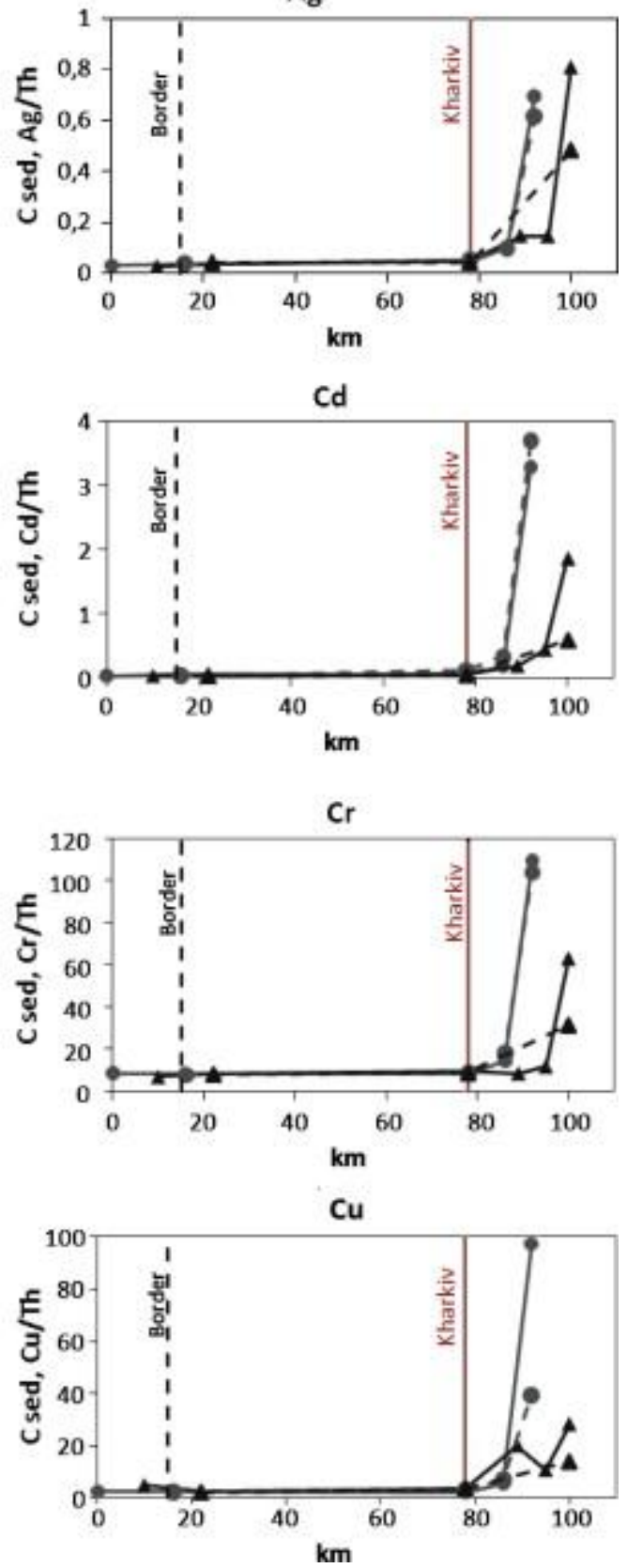

Fig. 2. Direct and Th-normalized concentrations of trace elements in the sediments of the Udy and Lopan Rivers. Udy R. (circles), Lopan R. (triangles), May sampling (solid line), August sampling (dashed line). 
Table 4. Enrichment Factors (EFs) calculated for the trace elements in sediments based on the Th-normalized values.

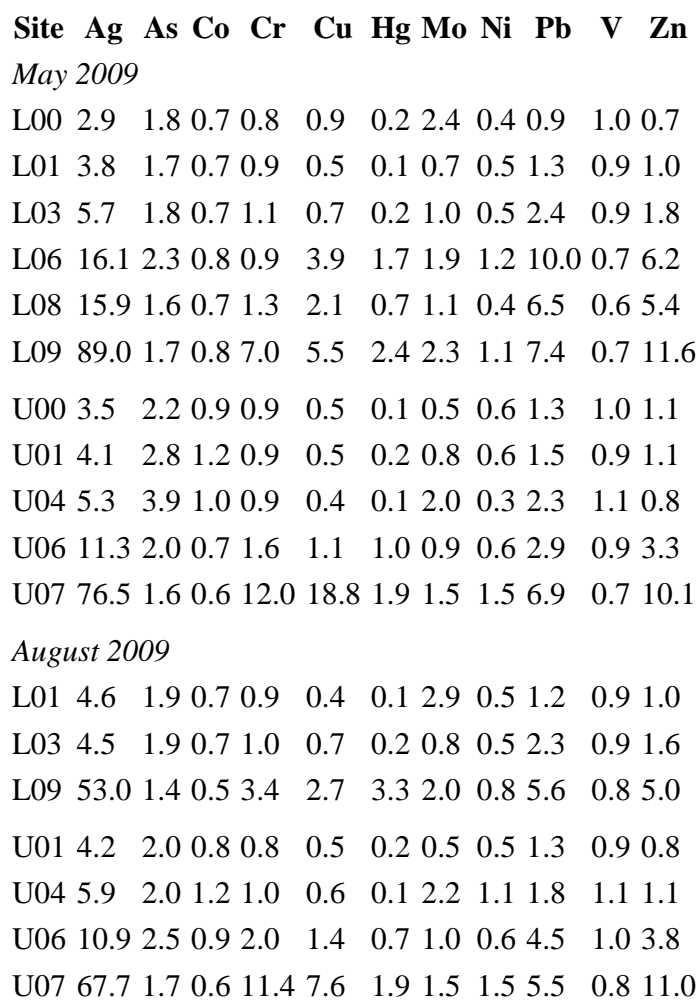

The Pearson's correlation between Th-normalized values has been determined between targeted trace elements $(n=5, p<0.05)$ ( Table 5 and Table 6$)$. In both the Lopan and Udy Rivers, positive correlations of the Th-normalized values were observed between $\mathrm{Ag}, \mathrm{Cd}, \mathrm{Cr}, \mathrm{Cu}, \mathrm{Hg}, \mathrm{Ni}, \mathrm{Pb}$ and $\mathrm{Zn}$ in May (Pearson's criterion, $r \geqslant 0.80)$ and in August $(r \geqslant 0.70)$. The spatial patterns of this element group are negatively correlated with those of $\mathrm{V}$ and $\mathrm{Co}(r \geqslant-0.70)$ and As $(r \geqslant-0.60)$ ( Table 5 and Table 6). However, in the Lopan River in May, Co had some positive correlation $(r \geqslant 0.72)$ with $\mathrm{As}, \mathrm{Ni}$ and $\mathrm{Cu}$, and $\mathrm{As}$ with $\mathrm{Cu}$ and $\mathrm{Ni}$, that may reflect different sources e.g. run-off and groundwaters for these elements during high and low-flow periods. 
Table 6. Pearson correlation matrix of Th-normalized values of trace elements in the sediments of the Lopan River $(n=5, p<0.05)$. The most significant correlations are in bold type.

\begin{tabular}{|c|c|c|c|c|c|c|c|c|c|c|c|c|}
\hline $\begin{array}{c}\text { May } \\
\text { August }\end{array}$ & $\mathbf{V}$ & $\mathrm{Cr}$ & Co & $\mathbf{N i}$ & $\mathrm{Cu}$ & $\mathbf{Z n}$ & As & Mo & Ag & Cd & $\mathbf{P b}$ & Hg \\
\hline V & 1 & -0.99 & 0.99 & -0.99 & -0.99 & -0.99 & 0.99 & -0.04 & -0.99 & -0.99 & -0.98 & -0.99 \\
\hline $\mathrm{Cr}$ & -0.26 & 1 & -0.99 & 0.99 & 0.99 & 0.99 & -0.99 & 0.06 & 0.99 & 0.99 & 0.98 & 0.99 \\
\hline Co & -0.12 & 0.52 & 1 & -0.99 & -0.99 & -0.99 & 0.99 & -0.04 & -0.99 & -0.99 & -0.98 & -0.99 \\
\hline $\mathrm{Ni}$ & -0.48 & 0.50 & 0.92 & 1 & 0.99 & 0.99 & -0.99 & -0.10 & 0.98 & 0.99 & 0.99 & 0.99 \\
\hline $\mathrm{Cu}$ & -0.65 & 0.79 & 0.73 & 0.86 & 1 & 0.99 & -0.99 & -0.02 & 0.99 & 0.99 & 0.99 & 0.99 \\
\hline $\mathrm{Zn}$ & -0.70 & 0.85 & 0.57 & 0.73 & 0.96 & 1 & -0.99 & -0.06 & 0.99 & 0.99 & 1.00 & 0.99 \\
\hline As & -0.16 & -0.18 & 0.72 & 0.74 & 0.32 & 0.10 & 1 & 0.01 & -0.99 & -0.99 & -0.99 & -0.99 \\
\hline Mo & -0.03 & 0.45 & 0.59 & 0.50 & 0.58 & 0.43 & 0.27 & 1 & 0.09 & 0.07 & -0.15 & 0.07 \\
\hline $\mathrm{Ag}$ & -0.38 & 0.99 & 0.57 & 0.59 & 0.86 & 0.92 & -0.09 & 0.48 & 1 & 0.99 & 0.97 & 0.99 \\
\hline $\mathrm{Cd}$ & -0.39 & 0.99 & 0.47 & 0.51 & 0.83 & 0.91 & -0.19 & 0.45 & 0.99 & 1 & 0.98 & 0.99 \\
\hline $\mathrm{Pb}$ & -0.89 & 0.38 & 0.53 & 0.81 & 0.84 & 0.80 & 0.50 & 0.29 & 0.50 & 0.47 & 1 & 0.97 \\
\hline $\mathrm{Hg}$ & -0.63 & 0.79 & 0.76 & 0.88 & 1.00 & 0.96 & 0.35 & 0.56 & 0.87 & 0.83 & 0.83 & 1 \\
\hline
\end{tabular}

\section{Discussion}

\subsection{Baseline of trace elements in the sediments}

Due to the long term anthropogenic exploitation of the Seversky Donets watershed, it is difficult to find a truly pristine area. Therefore, the regional baseline can be established as the expected range of element concentrations in sediment samples in an area without any geochemical anomalies (Williams et al., 2000; Singh et al., 2003 and Njofang et al., 2007).

Results for the sediment Th-normalization at the transboundary, upstream of the urban area sites showed that upstream influences on the geochemistry of the Udy and Lopan Rivers can be neglected compared to the impact of the Kharkiv urban area. Accordingly, the proposed present-day baseline values are the $75 \%$ quartile (Njofang et al., 2007) of the Th-normalized values obtained for the sites upstream of the urban area (Table 7). These values for Ag, As, $\mathrm{Cd}$, Mo and $\mathrm{Pb}$ were higher than the Th-normalized value of the Earth's crust proposed by Vinogradov (1962). Other Th-normalized trace element (Co, Cr, Cu, $\mathrm{Zn}$ and V) values were in agreement with the crustal values. The comparison of Th-normalized values obtained in this study with the Th-normalized values of world sediments (Reimann and De Caritat, 1998) showed that the proposed regional baseline concentrations for $\mathrm{Ag}, \mathrm{As}, \mathrm{Cr}, \mathrm{Cu}, \mathrm{Mo}, \mathrm{Ni}, \mathrm{Zn}$ and $\mathrm{V}$ are higher than those obtained from the world sediment composition. The values for Co and $\mathrm{Hg}$ are at the same level. 
Table 7. Summary of the statistics of the Th-normalized baseline values of trace elements in the sediments of the Udy and Lopan Rivers, at the sites upstream of the urban area (L00; L01; L03; U00; U01 and U04).

\begin{tabular}{|c|c|c|c|c|c|c|c|c|c|c|c|c|}
\hline Parameter & Ag/Th & As/Th & $\mathrm{Cd} / \mathrm{Th}$ & $\mathrm{Co} / \mathrm{Th}$ & $\mathrm{Cr} / \mathrm{Th}$ & $\mathrm{Cu} / \mathrm{Th}$ & $\mathrm{Hg} / \mathrm{Th}$ & Mo/Th & $\mathrm{Ni} / \mathrm{Th}$ & $\mathrm{Pb} / \mathrm{Th}$ & V/Th & $\mathrm{Zn} / \mathrm{Th}$ \\
\hline Average value ${ }^{c}$ & 0.04 & 1.32 & 0.05 & 1.59 & 8.27 & 3.03 & 0.01 & 0.25 & 4.77 & 2.98 & 11.4 & 8.03 \\
\hline Standard deviation & 0.01 & 0.39 & 0.03 & 0.36 & 0.75 & 0.79 & 0.002 & 0.16 & 1.81 & 0.96 & 1.06 & 2.52 \\
\hline Geometric value $^{c}$ & 0.04 & 1.28 & 0.05 & 1.56 & 8.24 & 2.95 & 0.01 & 0.21 & 4.54 & 2.84 & 11.3 & 7.71 \\
\hline Maximum value & 0.05 & 2.31 & 0.13 & 2.19 & 9.61 & 4.84 & 0.01 & 0.54 & 9.57 & 4.36 & 13.2 & 13.1 \\
\hline Minimum value & 0.03 & 1.05 & 0.03 & 1.25 & 6.85 & 2.22 & 0.003 & 0.09 & 2.83 & 1.72 & 10.1 & 4.98 \\
\hline Median value & 0.04 & 1.19 & 0.04 & 1.44 & 8.19 & 2.72 & 0.01 & 0.17 & 4.37 & 2.59 & 11.1 & 7.69 \\
\hline $25 \%$ quartile & 0.04 & 1.10 & 0.04 & 1.33 & 8.07 & 2.56 & 0.005 & 0.14 & 3.96 & 2.30 & 10.7 & 6.36 \\
\hline $75 \%$ quartile (baseline) & 0.05 & 1.32 & 0.06 & 1.83 & 8.66 & 3.38 & 0.01 & 0.39 & 4.91 & 3.95 & 11.8 & 8.00 \\
\hline Crust value $^{\mathrm{a}}$ & 0.01 & 0.06 & 0.003 & 1.82 & 9.09 & 5.18 & 0.04 & 0.18 & 8.64 & 1.82 & 11.82 & 7.27 \\
\hline World sediments values ${ }^{b}$ & 0.01 & 0.16 & 0.14 & 1.18 & 5.04 & 1.50 & 0.01 & 0.06 & 2.36 & - & 0.08 & 6.30 \\
\hline
\end{tabular}

$\mathrm{b}$

World sediments, according to Reimann and De Caritat (1998).

c

Average value (mean) considers that each value is independent from the others; geometric value (mean) considers that each value is dependent on the others.

\subsection{Environmental risk assessment of element concentrations in the sediments}

The environmental risk assessment of element concentrations in the studied sediments was performed for the sites located upstream of Kharkiv city (L03 and U04), central Kharkiv city (L06 and U06) and the sites downstream of the wastewater discharges (L09 and U07), which are also within the urban area with a high population density.

For this, element concentrations in the studied sediments were compared to the respective threshold effect concentration (TEC) and the Probable Effect Concentration (PEC) (Table 8). At the sites upstream of Kharkiv city only Cr exceeded the TEC in the Lopan River (L03). In the central part of Kharkiv city $\mathrm{Cu}$ exceeded the TEC in the Lopan River (L06) in May and in the Udy River (U06) in August. Chromium concentrations in the Udy River sediments (U06) exceeded the TEC in May and the PEC in August. In the downstream Lopan River (L09), Cd concentrations exceeded PEC in May. The estimates of $m-P E C-Q$ showed that element concentrations in the sediments must be considered as potentially dangerous for the environment at site L09 (Lopan River, May) (m-PEC $-Q=0.75$ ). 
Table 8. Environmental risk assessment for the sediments (not normalized) of the Lopan and Udy Rivers.

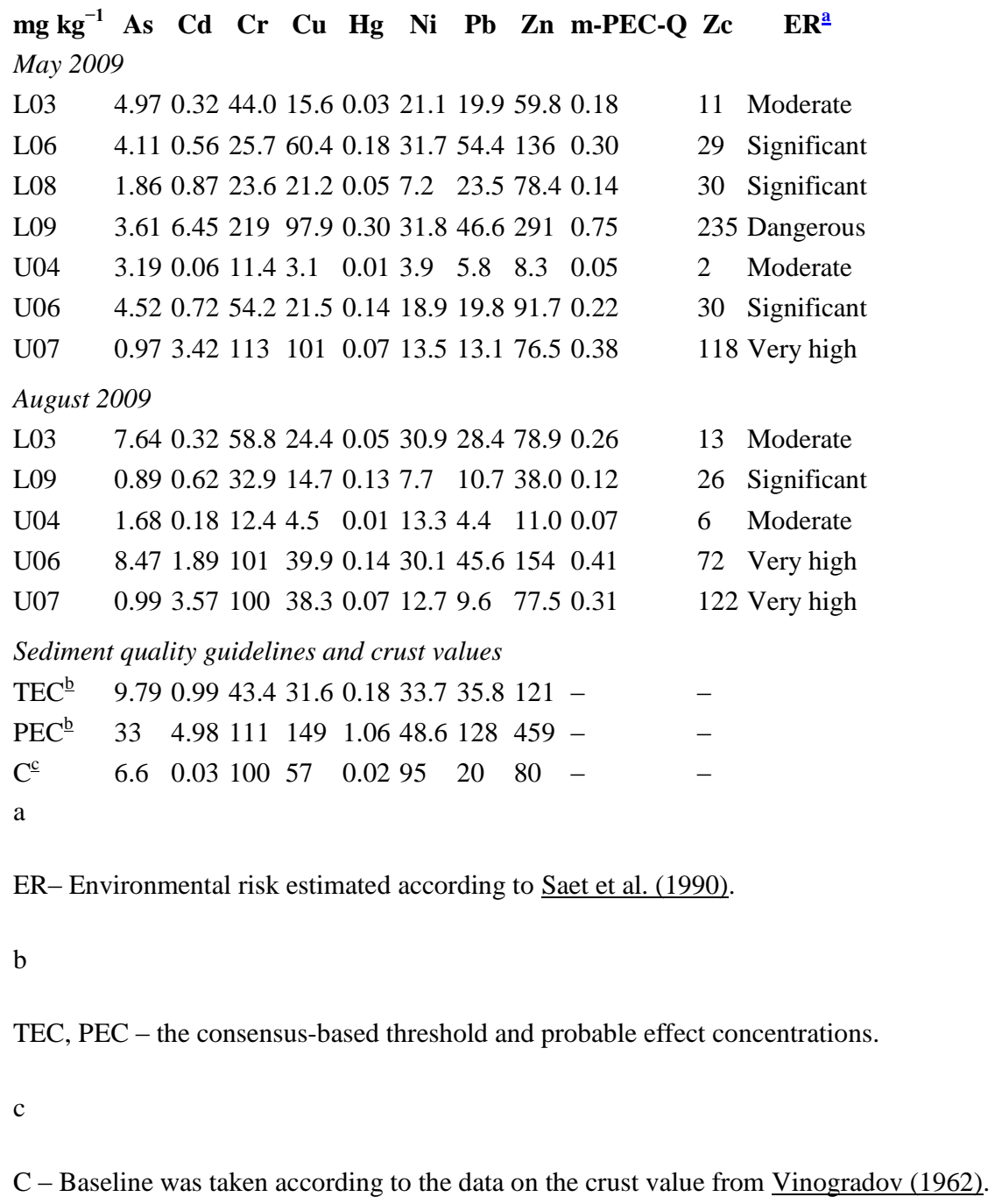

According to the Ukrainian environmental risk assessment protocol (Saet et al., 1990), the results of the environmental risk assessment in May were in agreement with those for August for all sampling sites, except the L09 site, where the observed difference probably reflects sediment heterogeneity and/or grain size effects. This confirms the necessity to normalize the data in order to avoid artefacts. Other results from the Ukrainian approach were consistent with the assessment calculated using the Sediment Quality Guideline. Accordingly, the contamination of the studied sediments varies from 'moderate' upstream of the city area to 'dangerous' downstream of Kharkiv city. In the city area the risk was estimated as 'significant' (L06, L08 and U06; May) and 'very high' (U06; August). Downstream of the wastewater treatment discharges, the degree of sediment pollution was evaluated as "very high' (Udy River; U06) and ‘dangerous' (Lopan River; L09).

Based on these environmental risk assessments the studied rivers can be divided into three parts: (1) low risk for the slightly contaminated upstream reaches (L03 and U04); (2) medium risk for central urban area (L06 and U06) and (3) high risk in the reaches downstream of the wastewater discharges (L09 and U07). High $\mathrm{Cr}$ and Zn concentrations are the main contributors to poor sediment quality at the sites downstream from the wastewater treatment 
plants. The poor sediment quality in the urban area reflects the historical and continued use of the Lopan and Udy Rivers as recipients for the discharge of polluted wastewaters.

\subsection{Normalization of trace element concentration with $\mathrm{Th}$}

In order to represent the spatial distribution patterns of trace elements in the sediments, normalization by Th has been applied in this study. Normalization of trace element concentrations in sediments with Th concentrations has proven to be efficient for nullifying grain size effects, allowing comparison of site-to-site variations in trace element concentrations for sediments from Thailand (Srisuksawad et al., 1997), Brazil (Ferreira et al., 2006) and France (Coynel et al., 2007 and Larrose et al., 2010). Thorium is virtually insoluble (van Calsteren and Thomas, 2006), is almost totally associated with detrital minerals, has few anthropogenic sources, and is inversely related to the grain size of the sediments. Thus, normalizing element concentrations with Th allows decoupling the variability of particulate element concentrations from the grain size distribution or mineralogical effects (Masson et al., 2009). The coefficient of variation (e.g. Reimann and De Caritat, 2005) for Th (30\%) was less than for other elements, i.e. $\mathrm{Ag}(117 \%)$, As (84\%), $\mathrm{Cr}(117 \%), \mathrm{Cu}(127 \%), \mathrm{Ni}(61 \%), \mathrm{Pb}$ (95\%) and Zn (91\%) in the sediments of the Lopan and Udy Rivers.

\subsection{Distribution and potential sources of trace elements in the sediments}

From the Th-normalized values and enrichments of trace elements in the sediments, correlation between them and distribution in the water, the studied elements were divided into two principle groups:

Group I - Ag, Cd, Cr, Cu, Hg, Ni, Pb and $\mathrm{Zn}$ - the correlation between the Th-normalized concentrations of these metals is relatively strong in both rivers, suggesting a common source, transport mechanism and behavior during different hydrological conditions. Enrichment Factors of these elements significantly increase in the urban area compared to rural parts of the watershed. Peaks of Th-normalized values for $\mathrm{Ag}, \mathrm{Cr}, \mathrm{Cu}, \mathrm{Cd}, \mathrm{Hg}$ and $\mathrm{Zn}$ occurred at the sampling sites downstream of the discharges from municipal wastewater treatment plants. The anthropogenic components, estimated as the difference between the Th-normalized values of these elements in sediments at the sites downstream of the wastewater discharge (L09 and U07) and upstream of the urban area (L03 and U04) were: Ag 91-94\%, Cd 92-99\%, Cr 7293\%, $\mathrm{Cu} 74-98 \%, \mathrm{Hg} 92-94 \%$, and $\mathrm{Zn} \mathrm{68-92 \%} \mathrm{which} \mathrm{were} \mathrm{mainly} \mathrm{attributed} \mathrm{to} \mathrm{wastewater}$ discharge from the WWTPs of the Kharkiv urban agglomeration. The 'B'WWTP and 'D' WWTP collect and treat mixed industrial effluent and domestic wastewaters from the city and suburban areas, and the treatment processes appear to be inefficient at reducing the contamination of trace metals in raw waters. The wastewater treatment system has not been improved since the establishment of the treatment facilities during the Soviet period (19641971).

The accumulation of $\mathrm{Pb}$ (anthropogenic component 60-76\%) and $\mathrm{Ni}$ (anthropogenic component $30-78 \%$ ) is probably related to urban run-off particles rather than wastewater effluents (Ohta et al., 2005, Schäfer et al., 2009 and Ayrault et al., 2010). The results for EF and anthropogenic components of metals in the sediments downstream of the wastewater treatment plants are in agreement with the data of Vasenko et al. (2006) who reported maximum $\mathrm{Cr}, \mathrm{Cu}, \mathrm{Zn}$ and $\mathrm{Pb}$ concentrations in the sediments of the Udy River in Kharkiv city. Additional sources of trace metals in water include roofs $(\mathrm{Zn})$ and traffic $(\mathrm{Cu}, \mathrm{Cd}$ and $\mathrm{Pb}$ ) (Ayrault et al., 2010). The strong accumulation of Ag in urban sediments confirms the 
usefulness of $\mathrm{Ag}$ as an urban tracer, supported by its low crustal abundance. A variety of sources in urban catchments include photographic-processing, dentistry (Feng et al., 1998) and domestic wastewaters (Guevara et al., 2005 and Lanceleur et al., 2011).

Group II - V, Co, As and Mo: these elements generally have negative correlations with the elements of Group I. Thus, these elements probably have different sources, transport mechanisms and behavior to those of Group I. In fact, there are no clear enrichments of As, Co, Mo and V in the Udy and Lopan Rivers (EF < 10) (Table 4). The stable spatial concentrations of dissolved Mo, $\mathrm{V}$ and Co (Table 3) are in agreement with the respective data for the sediments (Fig. 2) and confirmed the mainly natural origin of these elements in the rivers with low anthropogenic inputs.

Accordingly, the first group ( $\mathrm{Ag}, \mathrm{Cd}, \mathrm{Cr}, \mathrm{Cu}, \mathrm{Hg}, \mathrm{Ni}, \mathrm{Pb}$ and $\mathrm{Zn}$ ) shows increased enrichment in sediments from the urban area with high anthropogenic components of up to 99\% (Fig. 2). The second group (As, V, Mo and Co) relates mostly to the regional geochemical baseline of the sediments with very low enrichment in the urban area.

\section{Conclusions}

The results of the study showed that the distribution of trace elements in water and sediments of the Lopan and Udy Rivers of the Seversky Donets basin exhibits spatial variations. The analysis of dissolved element concentration in water and Th-normalized concentrations of metals in sediments indicates that the Kharkiv city area is the major source of $\mathrm{Ag}, \mathrm{Cd}, \mathrm{Cr}, \mathrm{Cu}$, $\mathrm{Hg}, \mathrm{Ni}, \mathrm{Pb}$ and $\mathrm{Zn}$ to the rivers. Based on the environmental risk assessment of the trace elements in the sediments, the rivers were divided into three parts: (i) low risk-relatively clean part in the upper sites; (ii) medium risk - urban polluted area and (iii) high risk-in the sites downstream of the wastewater discharges. The highest accumulation was observed for $\mathrm{Ag}$ with maximum contamination occurring in sampling sites located downstream from wastewater discharges. Silver shows strong correlation with other elements of anthropogenic origin and can be used as a reliable urban tracer.

In order to make the first step towards the development of a sediment quality guideline for the rivers in the Seversky Donets watershed, a present-day baseline concentration of the trace elements in the sediments was proposed based on the Th-normalized values. For new environmental data collection and the development of a water monitoring strategy in Ukraine, the proposed method of sampling (i.e. combination of grab and passive water monitoring and sediment analysis) and data interpretation (i.e. Th-normalization, estimation of EF and trace element baseline) can be applied to rivers with similar hydrological and geochemical characteristics.

This study is a part of a pilot for integrated research on urban rivers of the industrial East Ukraine region. For the presentation of a preliminary overview on the distribution of the elements in the watershed, the sampling was limited to just two campaigns. Further understanding of the speciation of the elements, mixing-dilution processes, continuous monitoring and replication should be carried out in contrasting seasonal and hydrological conditions including additional sites and the application of active and passive sampling techniques for long-term and diurnal investigations. 


\section{Acknowledgements}

This research was conducted in the framework of the International Collaborative Programme "Partenariat Hubert Curien DNIPRO" (Grant N 19744VJ 2009/2010) with financial support from both the French Ministry of Foreign Affairs and the Ukrainian Ministry of Education and Science. Some authors have received grants from the European Union through the ERASMUS MUNDUS External Cooperation Window Programme (Lot 6/7 - Belarus, Moldova and Ukraine) and from the Embassy of France to Ukraine (Bourse de Court Séjour de Recherche) and Eiffel Scholarship (France).

\section{References}

S. Audry, J. Schäfer, G. Blanc, C. Bossy, G. Lavaux

Anthropogenic components of heavy metal $(\mathrm{Cd}, \mathrm{Zn}, \mathrm{Cu}, \mathrm{Pb})$ budgets in the Lot - Garonne fluvial system (France)

Appl. Geochem., 19 (2004), pp. 769-786

S. Ayrault, A. Senhou, M. Moskura, A. Gaudry

Atmospheric trace element concentration in total suspended particles near Paris, France Atmos. Environ., 44 (2010), pp. 3700-3707

V.I. Belykh, E.I. Dunai, I.P. Lugovaya

Physicochemical formation conditions of banded iron formations and high-grade iron ores in the region of the Kursk Magnetic Anomaly: evidence from isotopic data

Geol. Ore Deposits, 49 (2007), pp. 147-159 (in Russian)

A. Binelli, S.K. Sarkar, M. Chatterjee, C. Riva, M. Parolini, B.D. Bhattacharya, A.K. Bhattacharya, K.K. Satpathy

A comparison of sediment quality guidelines for toxicity assessment in the Sunderban wetlands (Bay of Bengal, India)

Chemosphere, 73 (2008), pp. 1129-1137

B.S. Caruso, M. Bishop

Seasonal and spatial variation of metal loads from natural flows in the upper tenmile Greek watershed, Montana

Mine Water Environ., 28 (2009), pp. 166-181

M.C. Casado-Martinez, J.L. Buceta, M.J. Belzunce, T.A. Del Valls

Using sediment quality guidelines for dredged material management in commercial ports from Spain

Environ. Int., 32 (2006), pp. 388-396

R.B. Choueri, A. Cesar, D.M.S. Abessa, R.J. Torres, R.D. Morais, I. Riba, C.D.S. Pereira, M.R.L. Nascimento, A.A. Mozeto, T.A. DelValls

Development of site-specific sediment quality guidelines for North and South Atlantic littoral zones: comparison against national and international sediment quality benchmarks

J. Hazard. Mater., 170 (2009), pp. 320-331

A. Coynel, J. Schäfer, G. Blanc, C. Bossy

Scenario of particulate trace metal transport during a major flood event inferred from transient geochemical signals

Appl. Geochem., 22 (2007), pp. 821-836 
EPKhR, 2010. Environmental Passport of the Kharkiv Region. Ministry of the Environmental Protection. Ukraine, 2010. http://www.menr.gov.ua/content/article/5993 (in Ukrainian accessed 19.04.12).

H. Feng, J.K. Cochran, H. Lwiza, B.J. Brownawell, D.J. Hirschberg

Distribution of heavy metals and PCB contaminants in the sediments of an urban estuary: the Hudson River

Mar. Environ. Res., 45 (1998), pp. 69-88

J.R. Ferreira, E.A.N. Fernandes, E.S. Franca, G.A. Tavares, N.C. Da Silva, M.H.T. Taddei

Rare earth elements in sediment profiles from marginal lagoons of the Moji-Guacu River

Basin, Brazil

J. Radioanal. Nucl. Chem., 270 (2006), pp. 15-20

GCPL, 1991. General Code of Permitted Limits and Presumable Save Levels of Impacts of Hazardous Substances in the Waters use for Fishery (in Russian).

S.R. Guevara, M. Arribere, D. Bubach, P. Vigliano, A. Rizz, M. Alonso, R. Sancher

Silver contamination on abiotic and biotic compartments of Nahuel Huapi National Park

lakes, Patagonia, Argentina

Sci. Total Environ., 336 (2005), pp. 119-134

A. Gupta, D.K. Rai, R.S. Dandey, B. Sharma

Analysis of some heavy metals in the riverine water, sediments and fish from river Ganges at Allahabad

Environ. Monit. Assess., 157 (2009), pp. 449-458

C.G. Ingersoll, D.D. MacDonald, N. Wang, J.L. Crane, L.J. Field, P.S. Naverland, N.E. Kemple, R.A. Lindskoog, C. Severn, D.E. Smorong

Predictions of sediment toxicity using consensus based freshwater sediment quality guideline Arch. Environ. Contam. Toxicol., 41 (2001), pp. 8-21

V.V. Jakovljev, L.P. Svirenko, O.J. Chebanov, O.I. Spirin

Rising groundwater levels in north-eastern Ukraine: hazardous trends in Urban Areas

K.W.F. Howard, R.F. Israfilov (Eds.), Current Problems of Hydrogeology in Urban Areas

Urban Agglomerates and Industrial Centres, Kluwer Acad. Publ., Dordrecht (2002), pp. 221241 (NATO ARW Series)

L. Lanceleur, J. Schäfer, C. Bossy, A. Coynel, A. Larrose, M. Masson, G. Blanc

Silver fluxes to the Gironde Estuary - eleven years (1999-2009) of monitoring at the watershed scale

Appl. Geochem., 26 (2011), pp. 797-808

A. Larrose, A. Coynel, J. Schäfer, G. Blanc, L. Massé, E. Maneux

Assessing the current state of the Gironde Estuary by mapping priority contaminants

distribution and risk potential in surface sediment

Appl. Geochem., 25 (2010), pp. 1912-1923

D.D. MacDonald, C.G. Ingersoll, T.A. Berger

Development and evaluation of consensus-based sediment quality guidelines for freshwater ecosystems

Arch. Environ. Contam. Toxicol., 39 (2000), pp. 20-31 
M. Masson, J. Schäfer, G. Blanc, A. Dabrin, S. Castelle, G. Lavaux

Behavior of arsenic and antimony in the fresh water reaches of a highly turbid estuary, the Gironde Estuary, France

Appl. Geochem., 24 (2009), pp. 1747-1759

M.L. Matache, I.G. David, M. Matache, M. Ropota

Seasonal variation in trace metals concentrations in the Ialomita River, Romania

Environ. Monit. Assess., 153 (2009), pp. 273-279

K. Neumann, W.B. Lyons, E.Y. Graham, E. Callender

Historical backcasting of metal concentrations in the Chattahoochee River, Georgia:

population growth and environmental policy

Appl. Geochem., 20 (2005), pp. 2315-2324

C. Njofang, J. Matschullat, J.P. Tchouankoue, A. Amougou

Contribution to the geochemistry of trace elements in the sediments of the Noun River and tributaries, Western Cameroon

Pakistan J. Biol. Sci., 10 (2007), pp. 3048-3056

NRDW, 2006. National Report on Drinking Water Quality and Supply in 2006 year.

<http://www.minjkg.gov.ua/editattach/bigdoc/nd_voda2006.doc> (in Ukrainian, accessed 01.03.10).

A. Ohta, N. Imai, S. Terashima, Y. Tachbana

Application of multi-element statistical analysis for regional geochemical mapping in Central Japan

Appl. Geochem., 20 (2005), pp. 1017-1037

H. Pekey

The distribution and sources of heavy metals in Izmit Bay surface sediments affected by a polluted stream

Mar. Pollut. Bull., 52 (2006), pp. 1197-1208

C. Reimann, P. De Caritat

Chemical Elements in the Environment: Factsheets for the Geochemist and Environmental Scientist

Springer-Verlag, Berlin, Heidelberg (1998)

C. Reimann, P. De Caritat

Distinguishing between natural and anthropogenic sources of elements in the environment regional geochemical survey versus enrichment factors

Sci. Total Environ., 337 (2005), pp. 91-107

Y. Saet, B.A. Revych, E.P. Yanyn

Environmental Geochemistry

Nedra, Moscow (1990) (in Russian)

V.P. Samarina

The effect of a mining and smelting plant on the dynamics of heavy metals in small river basins in the zone of Kursk-Belgorod Magnetic Anomaly

Water Resour., 30 (2003), pp. 596-604 


\section{V.P. Samarina}

Assessment of the impact of economic activity on the degree of overland flow contamination in the zone of the Kursk-Belgorod Magnetic Anomaly: case study of the Oskol River

Water Resour., 34 (2007), pp. 549-553

V.P. Samarina

Effect of engineering-industrial activities in the region of the Kursk Magnetic Anomaly on the ecological state of the river waters

Geochem. Int., 46 (2008), pp. 928-934

J. Schäfer, G. Blanc

Relationship between ore deposits in river catchments and geochemistry of suspended particulate matter from six rivers in southwest France

Sci. Total Environ., 298 (2002), pp. 103-118

J. Schäfer, G. Blanc, S. Audry, D. Cossa, C. Bossy

Mercury in the Lot-Garonne River system (France). Sources, fluxes and anthropogenic component

Appl. Geochem., 21 (2006), pp. 515-527

J. Schäfer, S. Norra, D. Klein, G. Blanc

Mobility of trace metals associated with urban particles exposed to natural waters of various salinities from the Gironde Estuary, France

J. Soils Sed., 9 (2009), pp. 374-392

M. Singh, G. Muller, I.B. Singh

Geogenic distribution and baseline concentration of heavy metals in sediments of the Ganges

River, India

J. Geochem. Explor., 80 (2003), pp. 1-17

SNPL, 1991. Sanitary Norms of Permitted Limits of Hazardous Substances Contents in the Waters use for Drinking and Municipal Water use (in Russian).

K. Srisuksawad, B. Porntepkasemsan, L.S. Nouchpramool, P. Yamkate, R. Carpenter, M.L. Peterson, T. Hamilton

Radionuclide activities, geochemistry and accumulation rate of sediments in the Gulf of Thailand

Continent. Shelf Res., 17 (1997), pp. 925-965

Svirenko, L., Vergeles, Y., Jakovlev, V., 2003. Metal accumulation in soils and vegetation of river valleys in the city of Kharkiv, Ukraine. In: SUITMA 2003: Soils of Urban, Industrial, Traffic and Mining Areas: Final Program and Abstract Book. - Nancy, France, July 9-11, 2003.

I. Tueros, A. Borja, J. Larreta, J.G. Rodriguez, V. Valencia, E. Millan Integrating long-term water and sediment pollution data, in assessing chemical status within the European Water Framework Directive

Mar. Pollut. Bull., 58 (2009), pp. 1389-1400

P.V.C. van Calsteren, L. Thomas

Uranium-series dating applications in natural environmental science

Earth-Sci. Rev., 75 (2006), pp. 155-175 
D. van Hattum, N.M. van Straalen, H.A.J. Govers

Trace metals in populations of fresh isopods: influence of biotic and abiotic variables Arch. Environ. Contam. Toxicol., 31 (1996), pp. 303-318

Vasenko, O.G., Lungu, M.L., Iljevska, Y.A., Klymov, O.V., 2006. Research Report. The Integrated Field research of Environmental Conditions of Water Bodies of the Udy Water Basins (sub-basin of the Seversky Donets River)/“Rayder” Publ., Kharkiv. (in Ukrainian).

A.P. Vinogradov

Average element abundances in main types of eruptive rocks in the Earth's crust

Geokhimiya, 7 (1962), pp. 555-571 (in Russian)

Y. Vystavna, F. Huneau, P. Le Coustumer

Monitoring of biologically active metals forms in surface water: the results of passive sampling in the rivers of Ukraine and France, Water

Chem. Ecol., 12 (2009), pp. 2-9 (in Russian)

Y. Vystavna, F. Huneau, V. Grynenko, Y. Vergeles, H. Celle-Jeanton, N. Tapie, H. Budzinski, P. Le Coustumer

Pharmaceuticals in rivers of two different socio-economic regions: occurrence, accumulation and comparison for Ukraine and France

Water Air Soil Pollut. (2012) http://dx.doi.org/10.1007/s11270-011-1008-1

Y. Vystavna, F. Huneau, M. Motelica-Heino, P. Le Coustumer, Y. Vergeles, F. Stolberg

Monitoring and flux determination of trace metals in rivers of the Seversky Donets basin

(Ukraine) using DGT passive samplers

Environ. Earth Sci., 65 (2012), pp. 1715-1725

A.A. Yaroshevsky

Abundances of chemical elements in the Earth's crust

Geochem. Int., 44 (2006), pp. 48-55

N. Zheng, Q. Wang, Z. Liang, D. Zheng

Characterization of heavy metal concentrations in the sediments of three freshwater rivers in Huludao Ctiy, Northeast China

Environ. Pollut., 154 (2008), pp. 135-142 
Table 5. Pearson correlation matrix of Th-normalized values of trace elements in the sediments of the Udy River $(n=5, p<0.05)$. The most significant correlations are in bold type.

$\begin{array}{lllllllllllll}\begin{array}{c}\text { May } \\ \text { August }\end{array} & \mathbf{V} & \mathbf{C r} & \mathbf{C o} & \mathbf{N i} & \mathbf{C u} & \mathbf{Z n} & \mathbf{A s} & \mathbf{M o} & \mathbf{A g} & \mathbf{C d} & \mathbf{P b} & \mathbf{H g} \\ \mathrm{V} & 1 & -0.73 & \mathbf{0 . 9 7} & -0.27 & -0.72 & -0.68 & 0.58 & 0.50 & -0.72 & -0.72 & -0.45 & -0.77 \\ \mathrm{Cr} & -0.76 & 1 & -0.78 & 0.81 & \mathbf{0 . 9 9} & \mathbf{0 . 9 8} & -0.63 & 0.16 & \mathbf{0 . 9 9} & \mathbf{0 . 9 9} & 0.79 & \mathbf{0 . 9 0} \\ \mathrm{Co} & 0.48 & -0.68 & 1 & -0.29 & -0.78 & -0.78 & 0.44 & 0.48 & -0.78 & -0.78 & -0.63 & -\mathbf{0 . 8 6} \\ \mathrm{Ni} & -0.86 & \mathbf{0 . 9 7} & -0.67 & 1 & 0.81 & 0.76 & -0.69 & 0.70 & 0.82 & 0.82 & 0.53 & \mathbf{0 . 8 8} \\ \mathrm{Cu} & -0.76 & \mathbf{0 . 9 9} & -0.66 & \mathbf{0 . 9 7} & 1 & \mathbf{0 . 9 9} & -0.62 & 0.16 & \mathbf{0 . 9 9} & \mathbf{0 . 9 9} & 0.80 & \mathbf{0 . 8 9} \\ \mathrm{Zn} & -0.79 & \mathbf{0 . 9 8} & -0.78 & \mathbf{0 . 9 6} & \mathbf{0 . 9 7} & 1 & -0.48 & 0.13 & \mathbf{0 . 9 8} & \mathbf{0 . 9 8} & \mathbf{0 . 8 9} & \mathbf{0 . 9 7} \\ \mathrm{As} & 0.80 & -0.61 & 0.77 & -0.75 & -0.60 & -0.70 & 1 & -0.25 & -0.64 & -0.66 & -0.03 & -0.73 \\ \mathrm{Mo} & 0.20 & 0.34 & -0.04 & 0.12 & 0.34 & 0.27 & 0.48 & 1 & 0.17 & 0.18 & 0.07 & 0.22 \\ \mathrm{Ag} & -0.76 & \mathbf{0 . 9 9} & -0.70 & \mathbf{0 . 9 7} & \mathbf{0 . 9 9} & \mathbf{0 . 9 9} & -0.61 & 0.35 & 1 & \mathbf{0 . 9 9} & 0.79 & \mathbf{0 . 9 2} \\ \mathrm{Cd} & -0.76 & \mathbf{0 . 9 9} & -0.66 & \mathbf{0 . 9 7} & \mathbf{0 . 9 9} & \mathbf{0 . 9 8} & -0.60 & 0.34 & \mathbf{0 . 9 9} & 1 & 0.77 & \mathbf{0 . 8 9} \\ \mathrm{Pb} & -0.69 & \mathbf{0 . 9 7} & -0.74 & \mathbf{0 . 9 1} & \mathbf{0 . 9 7} & \mathbf{0 . 9 8} & -0.56 & 0.45 & \mathbf{0 . 9 8} & \mathbf{0 . 9 7} & 1 & \mathbf{0 . 9 5} \\ \mathrm{Hg} & -0.70 & \mathbf{0 . 9 8} & -0.80 & 0.73 & \mathbf{0 . 9 8} & \mathbf{0 . 9 9} & -0.47 & 0.10 & \mathbf{0 . 9 8} & \mathbf{0 . 9 7} & \mathbf{0 . 8 9} & 1\end{array}$

